\title{
Structural Configuration of the Otates Fault (Southern Basin and Range Province) and Its Rupture in the 3 May 1887
}

\section{$M_{\mathrm{W}} 7.5$ Sonora, Mexico, Earthquake}

\author{
by Max Suter
}

\begin{abstract}
During the great 3 May 1887 Sonoran earthquake (surface-rupture endto-end length: $101.8 \mathrm{~km} ; M_{\mathrm{W}} 7.5 \pm 0.3$ ), an array of three north-south-striking Basin and Range Province faults (from north to south: Pitáycachi, Teras, and Otates) slipped along the western margin of the Sierra Madre Occidental Plateau of northern Mexico. This detailed field survey of the previously undocumented 1887 earthquake rupture zone along the Otates fault includes mapping the rupture scarp and measurements of surface deformation at 25 sites. The surface rupture coincides with the mapped trace of the Otates fault, dips $68^{\circ} \mathrm{W}$, and has an end-point-to-end-point length of $18.2 \mathrm{~km}$. The lateral rupture terminations are controlled by cross faults. Striation measurements and the style of rupture indicate extensional dip slip without significant lateral displacement. The average shortening $(P)$ and extension $(T)$ kinematic axes inferred from the striations are similar to published composite focal mechanisms of the microseismicity recorded in the epicentral region of the 1887 earthquake. Based on surface deformation, maximum slip along the Otates fault in the 1887 earthquake was $270 \mathrm{~cm}$, and the average slip was $189 \mathrm{~cm}$. A quadratic best fit to the along-rupture surface offsets indicates an asymmetric distribution with the maximum offset near the northern end of the rupture segment, which can be explained by the mechanical interaction of the Teras and Otates surface-rupture segments through their stress fields. The average recurrence interval of 1887-sized earthquakes on the Otates fault is 30-42 kyr based on the long-term geologic dip-slip rate of the fault $(0.06 \mathrm{~mm} / \mathrm{yr})$ and its amount of slip in the 1887 earthquake.
\end{abstract}

Online Material: Color-coded elevation model, satellite image of major Basin and Range normal faults in the study area, color version of geologic map, and additional photographs.

\section{Introduction}

North-south-striking west-dipping Basin and Range Province normal faults and associated half-grabens form the western edge of the Sierra Madre Occidental Plateau in northeastern Sonora, Mexico, over a distance greater than $300 \mathrm{~km}$ (Fig. 1). Slip in 1887, within this segmented normalfault array, caused the largest historic earthquake of the southern Basin and Range tectonic-physiographic province and produced the world's longest recorded normal-fault surface rupture in historic time (dePolo et al., 1991; Yeats et al., 1997). Field observation indicates that three major rangebounding normal faults ruptured in the 1887 Sonoran earthquake (Suter and Contreras, 2002). The surface rupture dips $\sim 74^{\circ} \mathrm{W}$, has a maximum vertical displacement of $5.1 \mathrm{~m}$, and is composed, from south to north, of the Otates, Teras, and
Pitáycachi segments (Fig. 2; (E) Fig. S1 in the electronic edition of BSSA). These are the only Basin and Range Province faults in Mexico with known historical earthquake surface rupture. Including two isolated minor segments to the north of the Pitáycachi segment (Fig. 2), the 1887 rupture trace adds up to $86.7 \mathrm{~km}$, and the distance between the rupture trace extremities is $101.8 \mathrm{~km}$. Based on the endto-end length of the rupture trace and the length-versusmagnitude regression for normal faults by Wells and Coppersmith (1994), the $M_{\mathrm{W}}$ of this event is estimated as $7.5 \pm 0.3$.

This article provides detailed documentation of the Otates fault and the surface rupture along this fault, as well as historical evidence that the fault ruptured in the 1887 


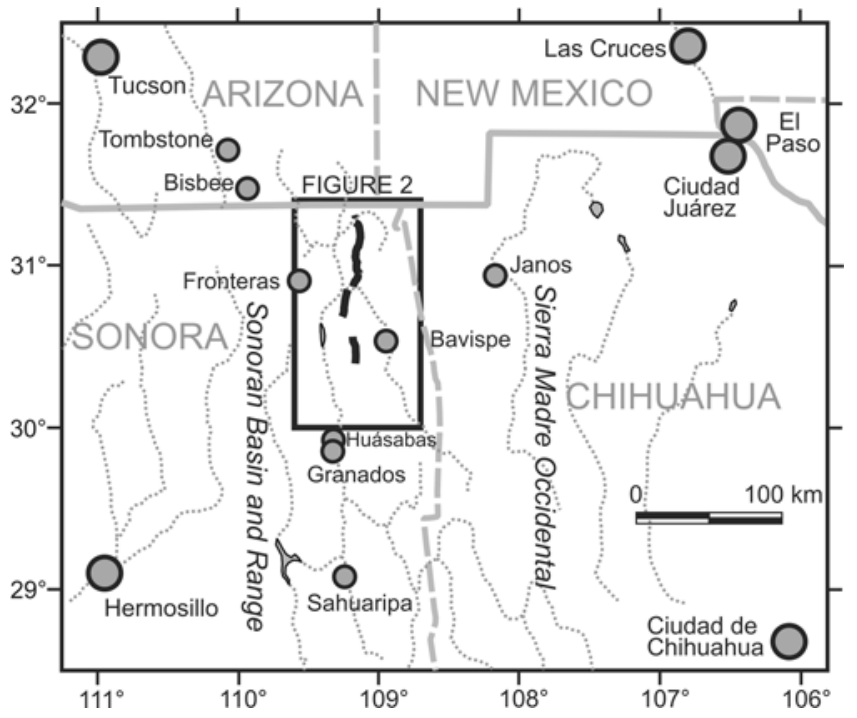

Figure 1. Location map showing the rupture trace of the 1887 Sonora, Mexico, earthquake (bold black lines). Gray solid line: international boundary; gray dashed lines: state boundaries; box: region depicted in Figure 2.

earthquake. A companion paper documents the Teras fault and its rupture in the 1887 earthquake (Suter, 2008). The 120-year-old rupture scarp is well exposed but was not previously studied, due in part to its location in a remote mountain region (Sierra El Tigre in Fig. 2; in early publications [Aguilera, 1888; Goodfellow, 1888] known as Sierra de Teras or Teras Mountains) within a large horseshoe-shaped bend of the Bavispe River ( $(E)$ Fig. S2 in the electronic edition of BSSA) in an area without permanent population and inaccessible by vehicle.

The study is based on field mapping, structural and morphological field measurements, and the structural interpretation of digital elevation models, aerial photographs, and satellite images. The first part of this article summarizes the stratigraphy and structural configuration of the Otates fault and provides reconnaissance data from the adjacent regionalscale Basin and Range Province structures (Fig. 3; (E) Fig. S2 in the electronic edition of $B S S A$ ). These regional geologic data are essential to the documentation and interpretation of the new earthquake-related field observations and the understanding of the structural interaction between the Otates and Teras faults. The second part presents, in detail, evidence for the surface rupture of the 1887 earthquake along the Otates fault. Ultimately, these data should be integrated into regional seismic hazard evaluations. They also contribute towards better kinematic models of complex interactions between earthquake rupture segments. Knowledge of the rupture geometry, slip distribution, and fault zone properties is also necessary to understand the spatial distribution of energy dissipation during coseismic slip (Kanamori and Rivera, 2006; Shipton et al., 2006). Moreover, a detailed map of the rupture geometry is a prerequisite to characteriz-

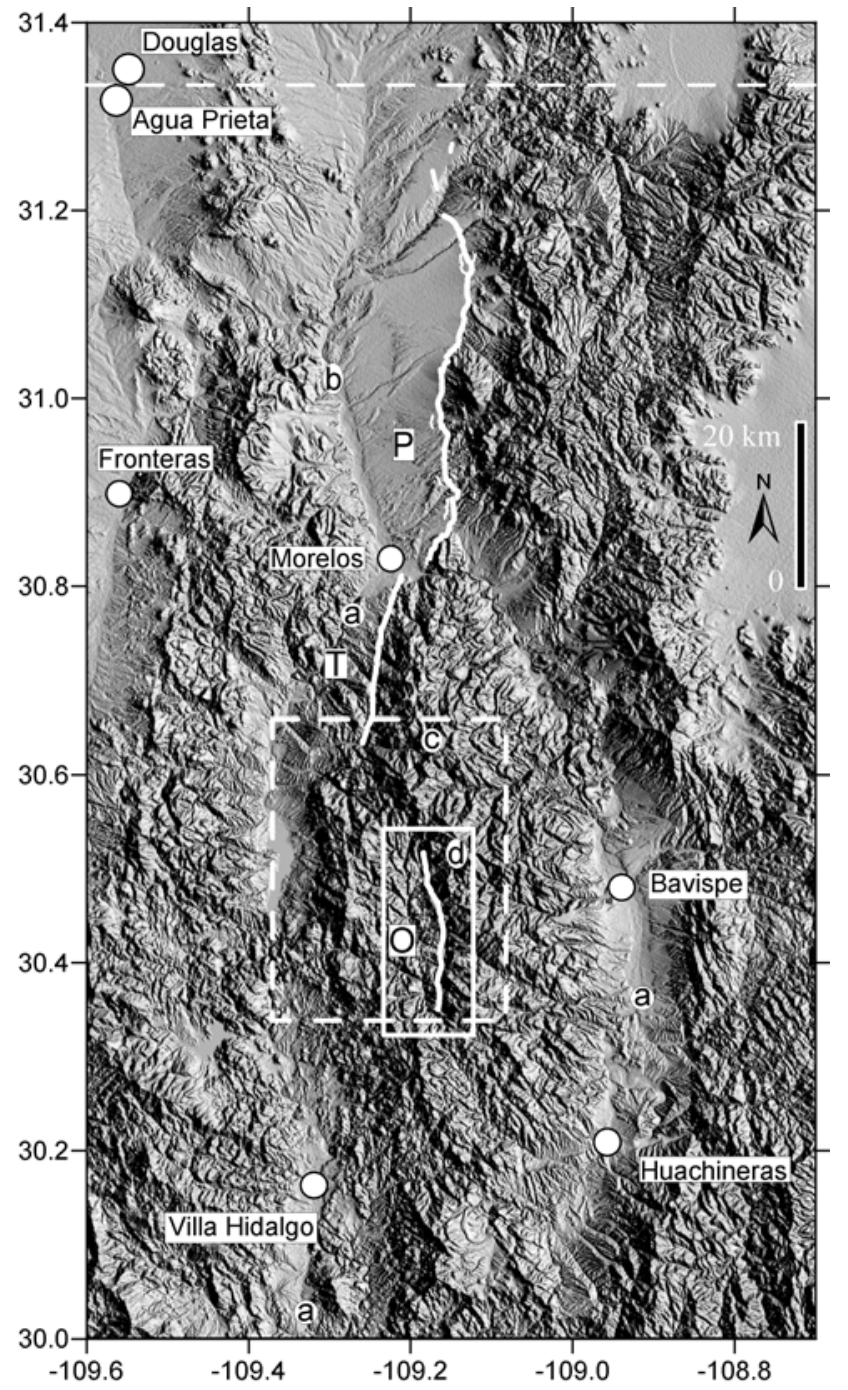

Figure 2. Digital elevation model of northeastern Sonora (location marked in Fig. 1). Rupture trace of the 1887 Sonoran earthquake marked by white bold lines (footwalls on the east side). P, Pitáycachi segment; T, Teras segment; O, Otates segment; a, Bavispe River; b, San Bernardino (Batepito) River; c, Sierra El Tigre (mountain range within the large horseshoe-shaped bend of the $\mathrm{Ba}-$ vispe River); d, Sierra La Madera; dashed white line: international boundary. Boxes: regions covered by Figures 3 (dashed outline) and 4 (solid outline).

ing the rupture propagation, rupture speed, and seismic-wave radiation of this earthquake.

\section{Geology of the Otates Fault Region}

\section{Stratigraphy}

The Otates fault separates the El Tigre horst from the Higueras basin (Figs. 3-6; (E) Figs. S1-S3 in the electronic edition of BSSA). Lithostratigraphic units in the footwall of the Otates fault include granitic basement rocks, Paleozoic limestone, early Oligocene felsic volcanic rocks, and Oligocene mafic volcanic rocks; lithostratigraphic units in the hanging wall of the fault include early Oligocene felsic vol- 


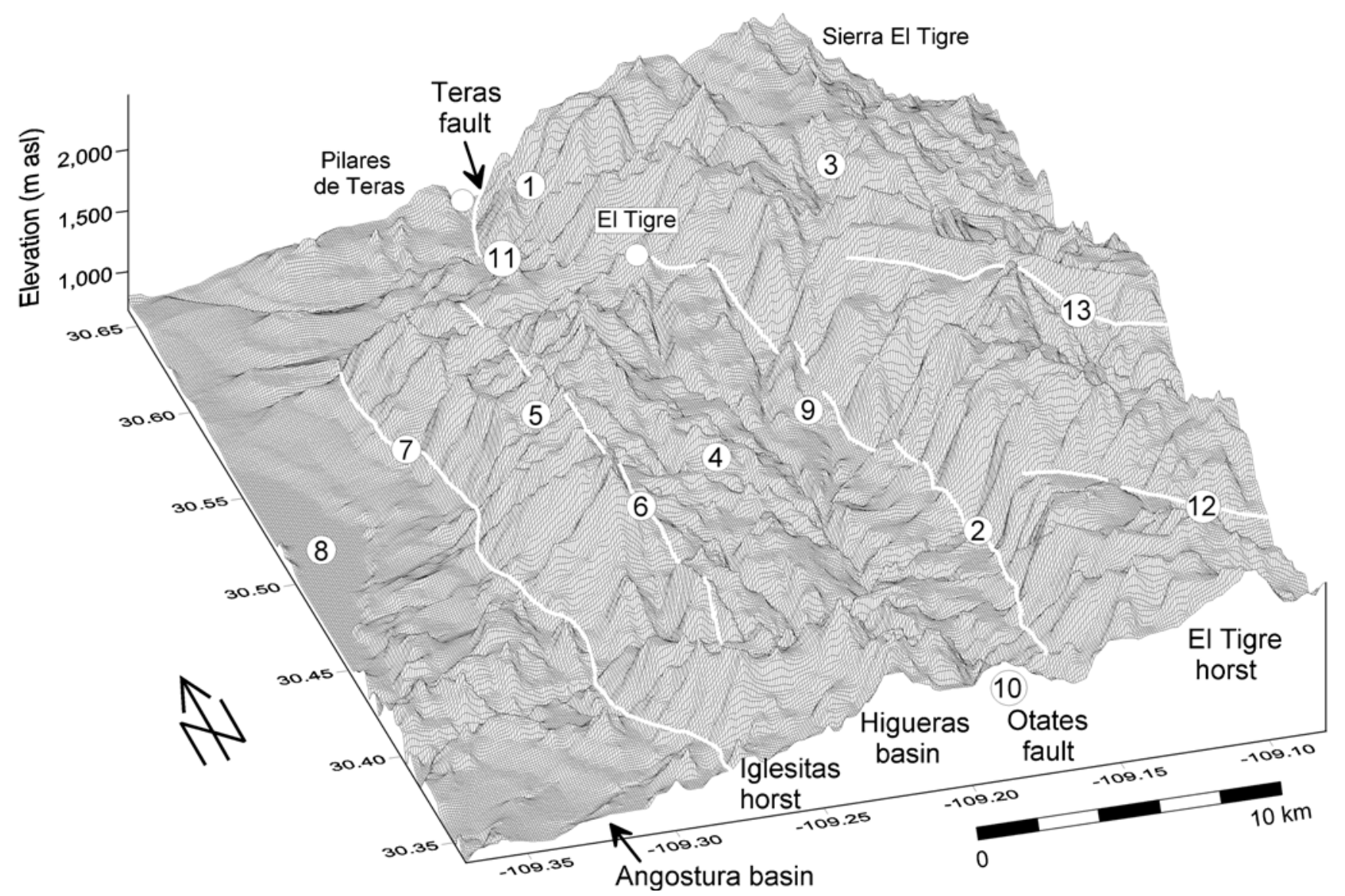

Figure 3. Terrain model showing the key tectonic and physiographic features of the study area. The view is from the southwest and $30^{\circ}$ from horizontal. The base of the block diagram is at $680 \mathrm{~m}$ and the maximum elevation at $2450 \mathrm{~m}$ ASL. The horizontal distance between neighboring wireframe nodes is $3 \operatorname{arcsec}(\sim 80 \mathrm{~m})$. The Basin and Range Province structures (approximate traces marked in white) are 1, Teras fault; 2, Otates fault; 3, footwall of the Otates fault, El Tigre horst; 4, hanging wall of the Otates fault, Higueras basin (Los Otates valley); 5, Iglesitas horst (Sierra Las Iglesitas); 6, normal fault delimiting the Iglesitas horst from the Higueras basin; 7, normal fault separating the Iglesitas horst from the Angostura basin; and 8, Angostura basin (now axially drained by the Bavispe River). 9 and 10 are the northern and southern ends, respectively, of the 1887 surface rupture on the Otates fault, and 11 is the southern extent of the 1887 surface rupture on the Teras fault. 12 and 13 are the traces of major northwest-southeast-striking faults within Sierra El Tigre.

canic rocks, Oligocene mafic volcanic rocks, the Miocene Báucarit conglomerate, and modern scree along the fault scarp (Fig. 4).

About $0.8 \mathrm{~km}^{2}$ of granitic basement (Mishler, 1920; Montaño-Jiménez, 1988) crop out at two locations within the footwall of the Otates fault, about $0.5-1.5 \mathrm{~km}$ west and southwest of the abandoned mining settlement of El Tigre (Fig. 3; (E) Figs. S1 and S2 in the electronic edition of BSSA); they are faulted against Tertiary felsic volcanic rocks. According to Montaño-Jiménez (1988), this granite is similar in composition and texture to the Precambrian Cananea granite, located $\sim 120 \mathrm{~km}$ west-northwest of El Tigre, which yielded a U-Pb isotope age of $1440 \pm 15 \mathrm{Ma}$ (Anderson and Silver, 1977). The Paleozoic limestone crops out $\left(\sim 0.2 \mathrm{~km}^{2}\right)$ northeast of El Ranchito, where it is faulted against Tertiary mafic volcanic rocks and scree (Fig. 4).

Tertiary ignimbrites, rhyolite, and rhyolitic tuff of the Sierra Madre Occidental volcanic province unconformably overlay the granite and Paleozoic limestone. These volcanic rocks are part of the Cordilleran magmatic arc system. They are mapped as a single unit in this study (Fig. 4), are up to $\sim 900 \mathrm{~m}$ thick, and occupy, by far, the largest footwall surface of the Otates fault (El Tigre horst). The upper part of this sequence yielded a $\mathrm{K}-\mathrm{Ar}$ age of $31 \pm 1.3 \mathrm{Ma}$ (early Oligocene) near the El Tigre mine (Montaño-Jiménez, 1988). Stratigraphically equivalent ignimbrites of the Boot Heel volcanic field in the southern Peloncillo Mountains, $100 \mathrm{~km}$ north of the Otates area, yielded ${ }^{40} \mathrm{Ar} /{ }^{39} \mathrm{Ar}$ ages of 26.8 35.1 Ma (McIntosh and Bryan, 2000). Within the study area, the felsic sequence is overlain by locally erupted basalt and mafic scoria (Fig. 4). In the Nacori Chico-Mesa Tres Ríos region, $80 \mathrm{~km}$ farther south, stratigraphically equivalent basalts have Oligocene K-Ar ages of 26-30 Ma (Montigny et al., 1987; Demant et al., 1989). In the Higueras basin, the mafic volcanic unit reaches a maximum thickness of 400 $500 \mathrm{~m}$ northwest of Las Gallinas ranch but is missing southeast of Tierra Larga and near La Loba ranch (Fig. 4). In the hanging wall of the Otates fault, this unit is overlain by the 


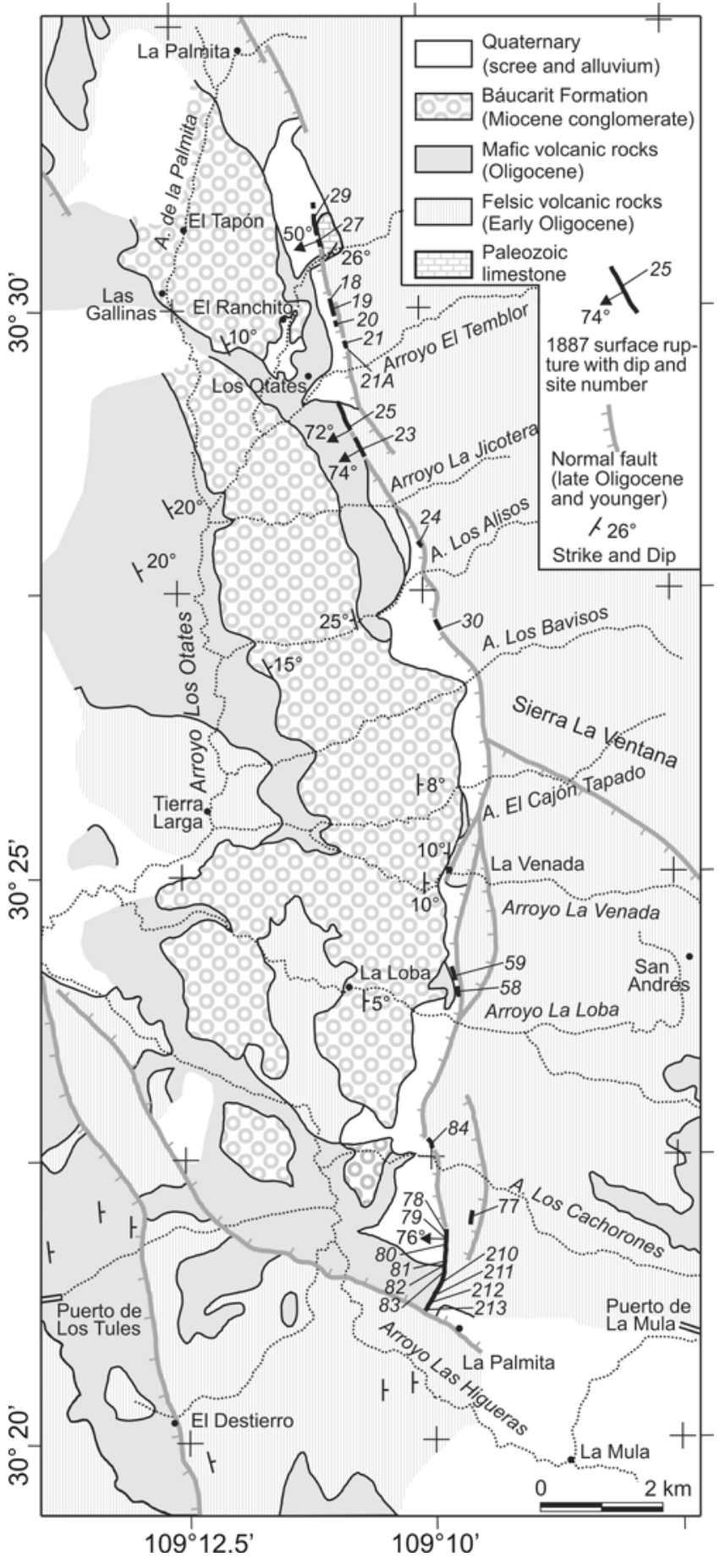

Figure 4. Geologic map showing the measurement sites on the rupture trace of the 1887 earthquake along the Otates fault. Open areas are unmapped. See (E) Figure S2 in the electronic edition of $B S S A$ for a color version of the map.

Miocene syntectonic Báucarit Formation (Figs. 4 and 5), which consists of well-indurated, poorly stratified conglomerate and sandstone deposited in the Higueras basin. The thickness of this basin fill is as much as $250 \mathrm{~m}$. Although originally hydrologically closed, the Higueras basin is now axially drained by Arroyo Los Otates (Fig. 4; (E) Fig. S2 in the electronic edition of BSSA). The modern drainage is incised into the Báucarit Formation and the underlying volcanic rocks (Fig. 4). Quaternary deposits are mostly scree except at El Ranchito, where alluvium has accumulated (Fig. 4). Contrary to the depositional setting along the Pitáycachi and Teras faults, there are no relicts of major alluvial fans along the Otates fault. One reason may be that the Otates fault is located at a higher elevation than the other two faults and well above the base level of the Bavispe River (Fig. 3; (E) Figs. S1 and S2 in the electronic edition of BSSA).

\section{Structural Configuration}

The Otates fault is $\sim 30 \mathrm{~km}$ long and strikes north-south. Its structural throw is $>1360 \mathrm{~m}$ in the central part of the fault and $1000 \mathrm{~m}$ at its southern end based on the offset of the boundary between the felsic and mafic volcanic sequences. In the northern part of the fault, Mishler (1920) estimated 450-900 m of throw across the fault. The highest elevations of Sierra El Tigre, $\sim 2440 \mathrm{~m}$ above sea level (ASL), are located along the fault scarp due to long-term footwall uplift (E) Fig. S1 in the electronic edition of BSSA). The average dip of the Otates fault at the surface is $68^{\circ} \mathrm{W}$. Movement on the Otates fault, and Basin and Range Province faulting in the region of the 1887 earthquake, initiated $23 \mathrm{Myr}$ ago as indicated by the age of basalt flows intercalated with the lowermost fill of nearby extensional basins (McDowell et al., 1997; González-León et al., 2000; Paz Moreno et al., 2003). We estimate a long-term dip-slip rate of $0.06 \mathrm{~mm} / \mathrm{yr}$ based on $23 \mathrm{Myr}$ of fault activity, a throw of $1360 \mathrm{~m}$, and a dip of $68^{\circ}$.

The southern two-thirds of the Otates fault, where the throw is largest, is characterized by a steep linear multievent bedrock escarpment (footwall block) mantled by scree. Here, footwall drainages have formed a series of short but deeply incised canyons (Figs. 3 and 4). Deposition of the Báucarit Formation in the adjacent Higueras basin and surface rupture from the 1887 earthquake are limited to this part of the Otates fault (Figs. 3 and 4; (E) Fig. S2 in the electronic edition of $B S S A$ ). The northern limit of the Báucarit basin fill and the northern end of the surface rupture approximately coincide with the junction of the Otates fault and a major northweststriking normal fault in its footwall (Fig. 3; (E) Fig. S2 in the electronic edition of BSSA). The hanging-wall rocks have been dragged along the Otates fault (see rotated basalt and Báucarit layers in Fig. 5 and dip measurements in Fig. 4). This normal drag is expressed by a strip of basalt along the northern part of the fault and isolated basalt outcrops close to the Otates fault near the La Loba and La Venada ranches (Fig. 4). The footwall rocks, on the other hand, are not significantly rotated along the fault. East of La Loba, a major fault-bounded shear lens of felsic volcanic rocks is downdropped along the Otates fault (Figs. 4 and 5). A minor fault stepover within the felsic volcanic unit near Los Otates ranch may correspond to a former fault segment boundary. No subsidiary faults exist within the hanging wall. In the south, the 


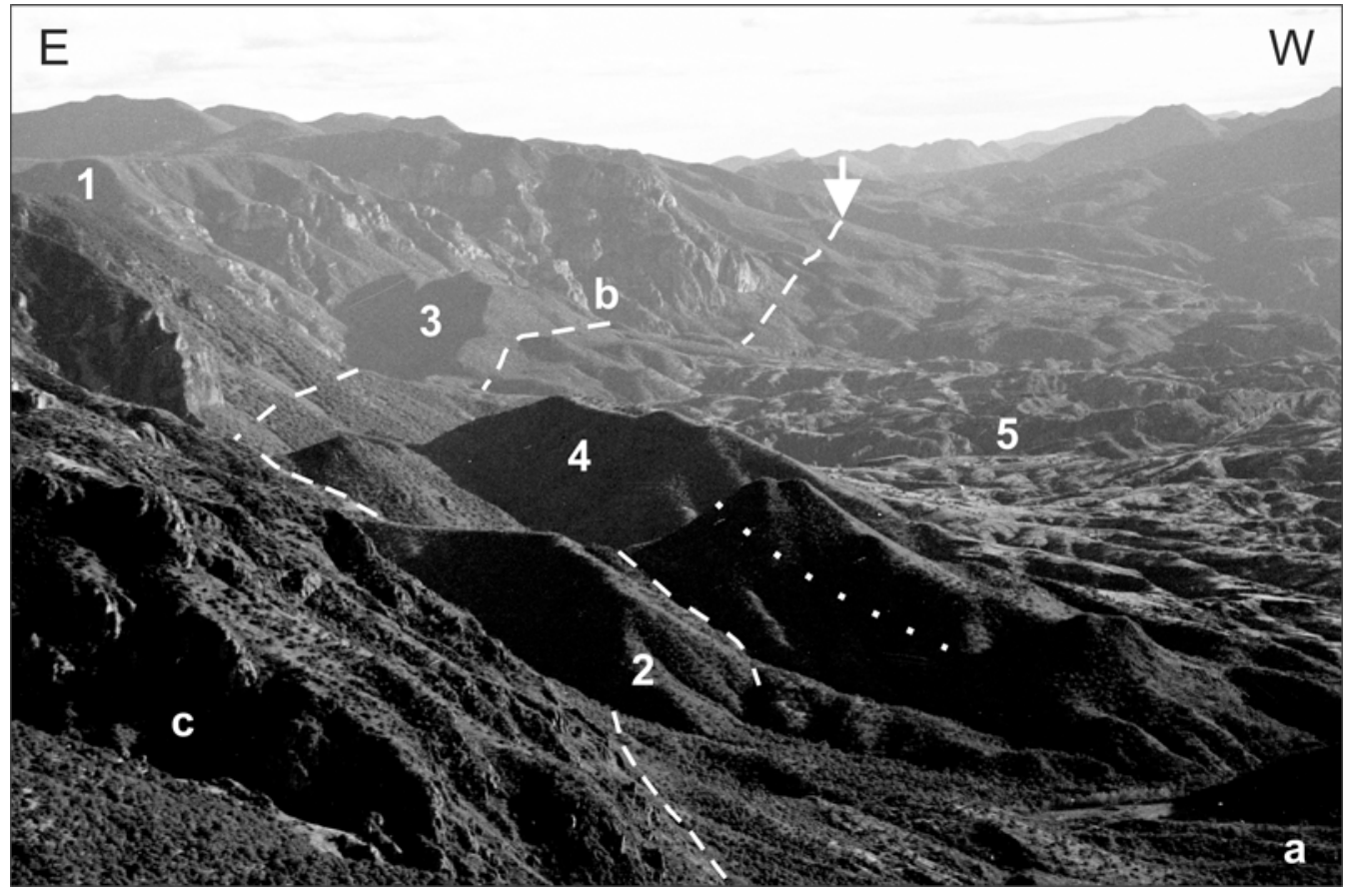

Figure 5. A view south along the Otates fault (see Fig. 4 for geologic map and geographic locations). The trace of the fault is marked by a dashed line; the arrow marks the southernmost documented outcrop of the 1887 surface rupture; 1 , Sierra El Tigre, rhyolitic footwall of the Otates fault; 2, minor stepover of the Otates fault as well as the 1887 surface rupture within rhyolite, southeast of Los Otates ranch; 3, major fault-bounded shear lens within felsic volcanic rocks; 4, drag-folded (dotted line) basalt within the hanging wall of the Otates fault in the Higueras basin; 5, Higueras basin fill (Báucarit Formation). (a) represents the Los Otates ranch, (b) the La Loba canyon, and (c) the El Temblor canyon.

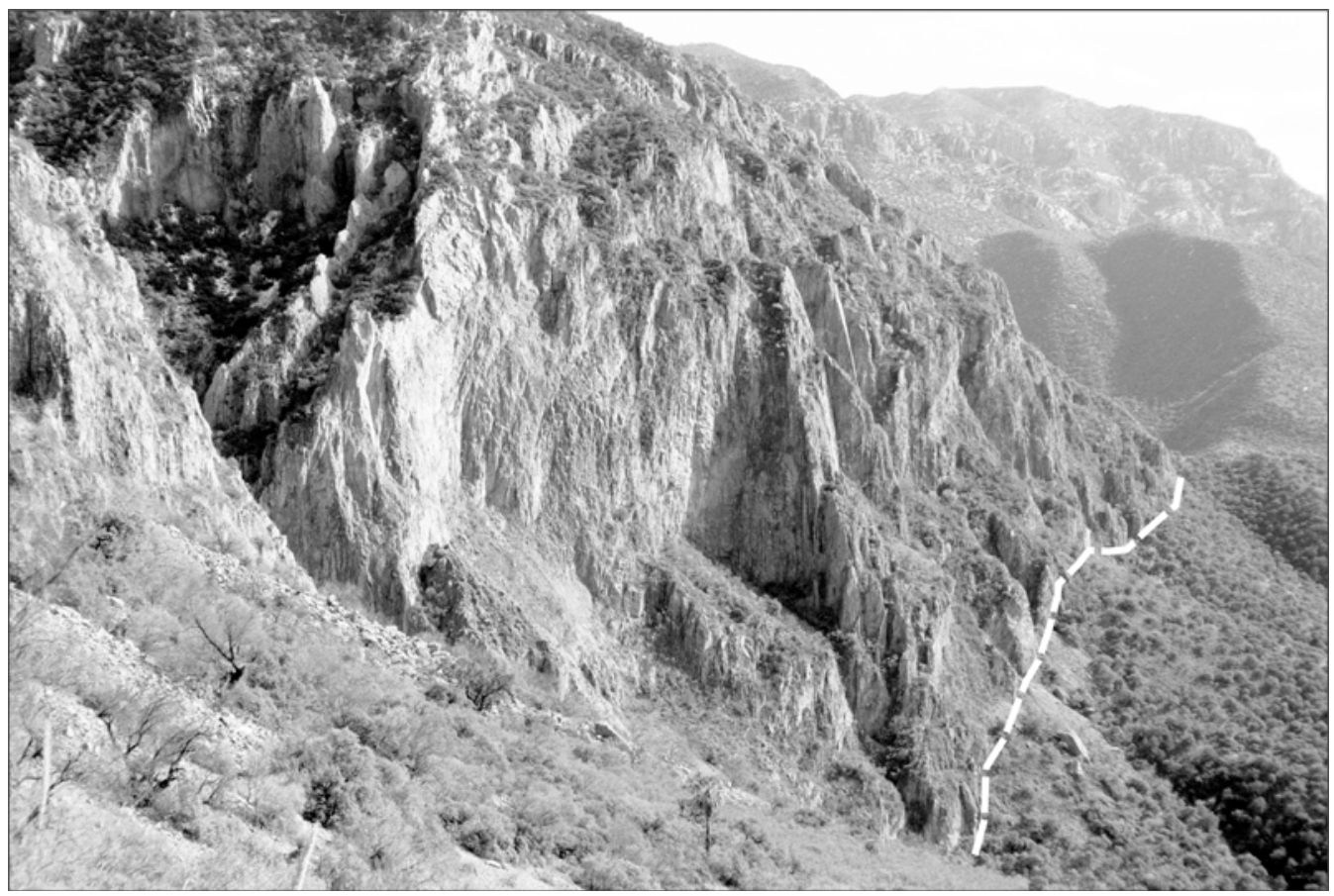

Figure 6. Photograph along the central part of the Otates fault looking south from site 30 (Fig. 4). Note the damage zone (brecciated rock), approximately $200 \mathrm{~m}$ wide, which is deformed by fracture cleavage and secondary faults within the footwall, adjacent to the master fault. The 1887 slip appears to be concentrated on the outer (western) limit of the damage zone (dashed line). 
Otates fault and the Higueras basin both terminate against the northwest-striking Palmita normal fault (Figs. 4 and 5; () Fig. S2 in the electronic edition of $B S S A$ ).

The northern third of the Otates fault is characterized by en echelon segments within early Oligocene felsic volcanics (Fig. 4), with two exceptions near El Tigre, where the volcanic rocks are faulted against Precambrian granite. There, the fault can be mapped where it forms prominent multievent footwall escarpments characterized by large shear planes and a cataclastic breccia zone. The northern fault termination is within the felsic volcanic unit west of the El Tigre mine (Fig. 3; (E) Fig. S2 in the electronic edition of BSSA). A basement high exists at the segment boundary between the Teras and Otates faults (Figs. 2 and 3). The segment boundary is characterized by a fault relay zone where the displacement of the Teras fault is transferred onto the Otates fault and the normal faults bounding the Iglesitas horst (Fig. 3; (E) Fig. S2 in the electronic edition of $B S S A$ ). Similar basement ridges have been observed to form structural barriers to fault rupture along other segmented normal-fault zones (Machette et al., 1991).

In cross section, the Otates fault is characterized by a steep footwall escarpment with little evidence for retreat and no pediment. Within the footwall, adjacent to the master fault, a cataclastic damage zone, $\sim 200 \mathrm{~m}$ wide, is deformed by secondary faults and fractures (Fig. 6). Damage-zone fractures are assumed to develop in a volume of rock surrounding the fault tip and are left behind the propagating tip as the fault grows (Vermilye and Scholz, 1998; Scholz, 2002). Coseismic shear displacement, on the other hand, is commonly localized to $<10 \mathrm{~cm}$ on planar faults (McCalpin, 1996; Sibson, 2003; Shipton et al., 2006). We estimate that much of the Otates damage zone, formed during along-strike propagation of the Otates fault tip, is no longer part of the active deformation zone. The 1887 slip appears to be concentrated on the outer (western) limit of the damage zone (Fig. 4).

\section{Regional-Scale Structure}

The faults of the Sonoran Basin and Range Province, including the Otates fault, are part of the ongoing extension that surrounds the less deformed plateau of the Sierra Madre Occidental (Stewart, 1998; Henry and Aranda-Gómez, 2000). Historical seismicity within the region is abundant (Orozco y Berra, 1887; Doser and Rodríguez, 1993; Yamamoto, 1993; García Acosta and Suárez Reynoso, 1996; Suter et al., 1996; Suter 2001; Suter and Contreras, 2002; Zúñiga et al., 2003). A number of faults in the Mexican part of the southern Basin and Range Province have been identified to have been active during the Quaternary (Nakata et al., 1982; Aranda-Gómez and Henry, 1992; Aranda-Gómez et al., 1997; Aranda-Gómez et al., 2003; Suter, 2004; Aguirre-Díaz et al., 2005). Borehole elongations in the Mexican part of the southern Basin and Range Province show that the least horizontal stress is oriented approximately east-west, per- pendicular to the traces of major normal faults (Suter, 1991). The 1993-2001 data sets from the Instituto Nacional de Estadística, Geografía e Informática (INEGI) continuous Global Positioning System stations Hermosillo and Culiacán indicate an upper limit of $3 \mathrm{~mm} / \mathrm{yr}$ of east-west to northeastsouthwest oriented extension in the Sonoran Basin and Range Province (Márquez-Azúa and DeMets, 2003).

Regional-scale structures in the Otates valley region include, from east to west, the El Tigre horst (footwall of the Otates and Teras faults), the Higueras basin (hanging wall of the Otates fault), the Iglesitas horst, and the Angostura basin (Fig. 3; (E) Fig. S2 in the electronic edition of BSSA). The Angostura and Higueras basins are about $10 \mathrm{~km}$ apart, and the Iglesitas and El Tigre horsts are $15 \mathrm{~km}$ apart. Presently, the geometry and history of the faults bounding these basins and horsts are only understood at a reconnaissance level. The north-south-striking fault separating the Iglesitas horst from the Angostura basin (Fig. 3) dips $56^{\circ}-78^{\circ} \mathrm{W}$; its throw is a minimum of $1420 \mathrm{~m}$. The fault separating the Iglesitas horst from the Higueras basin (Fig. 3) is nearly vertical and has a minimum throw of $1080 \mathrm{~m}$. Based on the geometry and estimated amount of throw along the Otates fault and the faults bordering the Iglesitas horst, there is an estimated $2300 \mathrm{~m}$ or $10 \%$ of extension between the Angostura basin and the El Tigre horst.

The Teras fault, which also ruptured in the 1887 earthquake (Fig. 2), extends from the piedmont alluvium southeast of the town of Morelos in the north to Arroyo de Las Carabinas in the south, where the trace shows a $60^{\circ}$ bend and jogs to the west (Suter, 2008; (E) Fig. S2 in the electronic edition of $B S S A$ ). There is a $6 \mathrm{~km}$ wide right step in the range-bounding normal-fault segments between the Teras fault and the fault delimiting the Iglesitas horst from the Angostura basin (Figs. 2 and 3). The step is partly breached by the dogleg of the Teras fault and by a major bend in the trace of the fault that delimits the Iglesitas horst from the Angostura basin (E) Fig. S2 in the electronic edition of $B S S A$ ). A major relay ramp is located south of this step where it leads to a transverse basement ridge. The region northwest of the ramp is a sediment sink characterized by large relict alluvial fans and three incised major creeks. The southern two of these creeks drain the transverse basement ridge, whereas the northern creek, which has by far the largest catchment area, drains the footwall of the Teras fault (Fig. 3; (E) Fig. S2 in the electronic edition of BSSA). Major sediment accumulation in the form of alluvial fans is typical at relay ramps of en echelon fault arrays (Jackson and Leeder, 1994; Gawthorpe and Leeder, 2000). This has been simulated by numerical experiments of the development of segmented normal-fault systems using a model integrating tectonics and surface processes (Contreras and Scholz, 2001).

\section{The 1887 Earthquake Rupture along the Otates Fault}

The 1887 earthquake has the longest normal-slip surface rupture in the worldwide historical record (dePolo et al., 
1991; Yeats et al., 1997). Previous studies of this earthquake focused on intensity distribution and attenuation (DuBois and Smith, 1980; Sbar and DuBois, 1984; Bakun, 2006), attenuation of local and regional earthquake body waves (Castro et al., 2008), historical seismicity of this region including isoseismal maps and a parametric earthquake catalog (Suter 2001), regional seismotectonics (Suter and Contreras, 2002), the geomorphology (Bull and Pearthree, 1988) and microseismicity (Natali and Sbar, 1982) of the Pitáycachi segment (Fig. 2), and the 1887 surface rupture along the Teras segment (Suter, 2008). Here, I provide a detailed characterization of the surface rupture of the 1887 earthquake along the Otates fault based on field observations. I mapped the surface rupture as well as the nearby geology at a 1:50,000 scale (Fig. 4) and studied the rupture scarp at 25 sites (Tables 1 and 2). At 23 of them, I measured the scarp morphology (width, height, and free face; Fig. 4; Table 1), and at four of them, I recorded slickenside data (Table 2). At several sites, the scarp is bounded by a major fissure (Fig. 8; Table 1). At these sites, the scarp height and width were measured across the fissure. I also noted the material exposed by the fault at each site and, in the case of rock debris, the fragment size and whether the material was cemented or not. Furthermore, I photographed the 120-year-old rupture scarp at many of the sites (Fig. 8; (E) Figs. S4-S10 in the electronic edition of $B S S A$ ).

\section{Scarp Morphology}

The range-bounding fault ruptured through scree slopes as steep as $31^{\circ}$ (Table 1; Fig. 4; (E) Figs. S5-S7 in the electronic edition of BSSA). This contrasts with the fault trace along the Pitáycachi segment, which typically displaces lowangle $\left(<6^{\circ}\right)$ piedmont surfaces (Bull and Pearthree, 1988). At a few sites, such as 23, 25, 27, and 79 (Fig. 4), the surface rupture is at the bedrock/scree contact (E) Fig. S4 in the electronic edition of BSSA), whereas at most sites the surface rupture is located within scree, only a few meters from the stratigraphic contact with bedrock ( $($ E) Figs. S6-S8 in the electronic edition of $B S S A$ ). Therefore, the rupture likely separates (except at a shallow depth) bedrock from scree and basin fill and is likely to coincide with the Otates fault. Warping of the ground surface was not apparent near the rupture trace, which suggests that the near-surface rupture is planar.

Continuous outcrops of the surface rupture are present at both segment ends (Fig. 4), where the structural and topographic relief of the Otates fault tapers off. In contrast, along the central part of the Otates segment (Fig. 4), where the throw of the Otates fault, topographic relief of the multievent fault scarp, and 1887 surface offset are all at their maximum (Table 1; Fig. 9), the rupture scarp is only visible on some isolated spurs (E) Fig. S5 in the electronic edition of BSSA). According to the local population, the rupture scarp and

Table 1

Scarp Parameters along the 1887 Surface Rupture of the Otates Fault

\begin{tabular}{|c|c|c|c|c|c|c|c|c|c|c|c|}
\hline Site & $\begin{array}{l}\text { Longitude } \\
\left({ }^{\circ} \mathrm{W}\right)\end{array}$ & $\begin{array}{l}\text { Latitude } \\
\left({ }^{\circ} \mathrm{N}\right)\end{array}$ & $\begin{array}{l}\text { Cumulative } \\
\text { Distance }(\mathrm{km})\end{array}$ & $\begin{array}{l}\text { Elevation } \\
(\mathrm{m})\end{array}$ & $\begin{array}{l}\text { Scarp Height } \\
(\mathrm{cm})\end{array}$ & $\begin{array}{l}\text { Scarp Width } \\
(\mathrm{cm})\end{array}$ & $\begin{array}{c}\text { Scarp } \\
\text { Slope }\left(^{\circ}\right)\end{array}$ & $\begin{array}{l}\text { Free Face } \\
(\mathrm{cm})\end{array}$ & $\begin{array}{l}\text { Fissure } \\
(\mathrm{Y} / \mathrm{N})\end{array}$ & $\begin{array}{l}\text { Surface } \\
\text { Slope }\left({ }^{\circ}\right)\end{array}$ & $\begin{array}{l}\text { Surface Offset } \\
(\mathrm{cm})\end{array}$ \\
\hline 29 & 109.184 & 30.513 & 0.30 & 1350 & 160 & 0 & 90.0 & 160 & $\mathrm{~N}$ & 11 & 160 \\
\hline 18 & 109.182 & 30.501 & 1.60 & 1310 & 290 & 250 & 49.2 & 215 & $\mathrm{~N}$ & 18 & $209^{\dagger}$ \\
\hline 19 & 109.181 & 30.500 & 1.80 & 1320 & 210 & 0 & 90.0 & 210 & $\mathrm{~N}$ & 18 & 210 \\
\hline 20 & 109.181 & 30.498 & 2.10 & 1335 & 230 & 240 & 43.8 & 200 & $\mathrm{~N}$ & 22 & $133^{\dagger}$ \\
\hline 21 & 109.179 & 30.495 & 2.45 & 1290 & 230 & 180 & 52.0 & 160 & $\mathrm{~N}$ & 22 & $157^{\dagger}$ \\
\hline $21 \mathrm{~A}$ & 109.179 & 30.494 & 2.50 & 1290 & 260 & 250 & 46.1 & 180 & $\mathrm{~N}$ & 22 & $159^{\dagger}$ \\
\hline 25 & 109.179 & 30.482 & 3.80 & 1300 & 250 & 145 & 59.9 & 250 & $\mathrm{~N}$ & 24 & $185^{\dagger}$ \\
\hline 24 & 109.167 & 30.465 & 6.00 & 1560 & 220 & 180 & 50.7 & 140 & $\mathrm{~N}$ & 27 & $128^{\dagger}$ \\
\hline 30 & 109.164 & 30.452 & 7.40 & 1620 & 377 & 264 & 55.0 & 220 & $\mathrm{~N}$ & 31 & $218^{\dagger}$ \\
\hline 59 & 109.162 & 30.402 & 13.60 & 1340 & 220 & 270 & 39.2 & 110 & $\mathrm{Y}$ & 22 & 111 \\
\hline 58 & 109.162 & 30.399 & 13.90 & 1290 & 280 & 380 & 36.4 & 180 & $\mathrm{~N}$ & 22 & $126^{\dagger}$ \\
\hline 84 & 109.167 & 30.377 & 16.50 & 1330 & 185 & 210 & 41.4 & 160 & $\mathrm{Y}$ & 22 & $100^{\dagger}$ \\
\hline $77^{*}$ & 109.160 & 30.366 & 17.70 & 1690 & 75 & 220 & 18.8 & 30 & Y & 18 & 4 \\
\hline 78 & 109.164 & 30.364 & 18.00 & 1470 & 165 & 80 & 64.1 & 110 & $\mathrm{~N}$ & 22 & 133 \\
\hline 79 & 109.164 & 30.363 & 18.10 & 1470 & 170 & 145 & 49.5 & 110 & $\mathrm{~N}$ & 15 & 131 \\
\hline 80 & 109.165 & 30.362 & 18.20 & 1470 & 195 & 365 & 28.1 & 160 & $\mathrm{Y}$ & 17 & $83^{\dagger}$ \\
\hline 81 & 109.165 & 30.360 & 18.45 & 1490 & 185 & 165 & 48.3 & 100 & $\mathrm{~N}$ & 11 & 152 \\
\hline 82 & 109.165 & 30.359 & 18.55 & 1500 & 165 & 135 & 50.7 & 150 & $\mathrm{~N}$ & 15 & $129^{\dagger}$ \\
\hline 83 & 109.165 & 30.358 & 18.65 & 1520 & 175 & 180 & 44.2 & 110 & $\mathrm{~N}$ & 15 & 127 \\
\hline 210 & 109.165 & 30.356 & 18.85 & 1490 & 195 & 210 & 42.9 & 160 & $\mathrm{~N}$ & 15 & $139^{\dagger}$ \\
\hline 211 & 109.167 & 30.355 & 19.10 & 1460 & 155 & 235 & 33.4 & 130 & $\mathrm{Y}$ & 22 & $60^{\dagger}$ \\
\hline 212 & 109.167 & 30.354 & 19.25 & 1440 & 170 & 200 & 40.4 & 90 & $\mathrm{~N}$ & 22 & $89^{\dagger}$ \\
\hline 213 & 109.168 & 30.353 & 19.40 & 1400 & 130 & 150 & 40.9 & 70 & $\mathrm{~N}$ & 22 & $69^{\dagger}$ \\
\hline
\end{tabular}

The measurements $(n=23)$ are listed from north to south. The sites are marked in Figure 4. Horizontal datum: NAD27. The scarp parameters are defined in Figure 7.

"This site is not located on the main rupture but on a subsidiary fault (Fig. 4).

${ }^{\dagger}$ At these sites, the computed surface offset is smaller than the measured free face (see text for further explanation). 
Table 2

Fault Planes and Slip Vectors (Striations) Measured on the Surface of the 1887 Rupture

\begin{tabular}{ccccccccc}
\hline Site & Longitude $\left({ }^{\circ} \mathrm{W}\right)$ & Latitude $\left({ }^{\circ} \mathrm{N}\right)$ & Elevation $(\mathrm{m})$ & Strike $\left({ }^{\circ}\right)$ & Dip $\left({ }^{\circ} \mathrm{W}\right)$ & Rake $\left(^{\circ}\right)$ & Lithology & Type of Motion \\
\hline 27 & 109.183 & 30.510 & 1280 & 179 & 50 & 90 & limestone & $\mathrm{N}$ \\
25 & 109.179 & 30.482 & 1300 & 176 & 72 & 90 & rhyolite & $\mathrm{N}$ \\
23 & 109.177 & 30.479 & 1390 & 153 & 74 & 105 & rhyolite & N-RL \\
79 & 109.165 & 30.363 & 1470 & 175 & 76 & 90 & rhyolite & $\mathrm{N}$ \\
\hline
\end{tabular}

The sites are listed from north to south (Fig. 4). Horizontal datum: NAD27. N denotes normal motion; N-RL denotes normal right-lateral motion.

basal fissure were more continuous 40 years ago along the central part of the Otates segment. However, the free face (fault scarp steeper than the angle of repose, Fig. 7) still exists at all 23 observation sites (Table 1). This suggests that the scarp is not so much eroding as being gradually covered by fresh rock debris (E) Figs. S5 and S6 in the electronic edition of $B S S A)$. The rupture scarp now slopes $33^{\circ}-64^{\circ}$ (Table 1) except where the scree is cemented (Fig. 8; (E) Fig. S10 in the electronic edition of BSSA) and the scarp for that reason still subvertical. The rock debris are coarse and poorly stratified and therefore not suitable for paleoseismological trenching investigation (E) Figs. S6 and S8 in the electronic edition of BSSA).

The surface offset (vertical separation of the ground surface) was calculated from the scarp height and slope angle above and below the scarp (Fig. 7) (Bucknam and Anderson, 1979; McCalpin, 1996; Yeats et al., 1997). Because of the steep (up to $31^{\circ}$ ) inclined slopes adjacent to the 1887 rupture, the surface offset deviates significantly from the scarp height. For most sites, the calculated surface offset is smaller than the (vertically) measured free face (Table 1) and therefore not useful. This problem did not arise with any of the numerous surface offsets calculated for the Pitáycachi segment (M. Suter, unpublished data, 2008) and only with three of the 27 surface offsets computed for the Teras segment (Suter, 2008). Because of the steep slopes along the Otates fault (Table 1), the base of the rupture scarp is often not well defined unless marked by a basal fissure. The transition from the small debris apron at the base of the scarp (Fig. 7) to the steep hillslope below is often gradual. Furthermore, the surface slope values used to calculate the surface offset have an uncertainty of $\pm 2^{\circ}$; they were taken from the corresponding INEGI 1:50,000 scale topographic map sheets, which have $20 \mathrm{~m}$ contour intervals. The most reliable measured scarp parameter, the free face (Fig. 7), gives a minimum estimate for the surface offset, whereas the scarp height gives a maximum estimate. For sites where the computed surface offset (Fig. 7) is smaller than the measured free face (Table 1), I assumed that the offset was not more than the free face value (Fig. 9). This assumption provides a minimum value for the vertical separation of the ground surface.

\section{Rupture Geometry}

The end points of the documented surface rupture along the Otates fault are located in the south at $109.168^{\circ} \mathrm{W}$, $30.352^{\circ} \mathrm{N}$ (horizontal datum: NAD27) and in the north at $109.184^{\circ} \mathrm{W}, 30.516^{\circ} \mathrm{N}$, both at an elevation of $1380 \mathrm{~m} \mathrm{ASL}$ (Fig. 4). The surface-rupture length is about $19.5 \mathrm{~km}$ (Fig. 9) with an end-point-to-end-point distance of $18.2 \mathrm{~km}$. The southern end point is on the northern slope of the valley that leads to the La Palmita ranch, where the rupture terminates against the northwest-southeast-striking regional-scale Palmita cross fault that passes within the same valley (Fig. 4; (E) Figs. S2 and S3 in the electronic edition of BSSA). Both the southern end of the Otates fault and the cross fault displace rhyolite against basalt (Fig. 4). The southern surface-rupture end point is $400 \mathrm{~m}$ farther south than reported in Suter and Contreras (2002). This brings the length of the entire 1887 surface rupture (Fig. 2) to $101.8 \mathrm{~km}$. Based on this distance and the scaling relation between rupture length and magnitude for normal faults (Wells and Coppersmith, 1994), the 1887 earthquake is now estimated at $M_{\mathrm{W}} 7.5 \pm 0.3$.

The northernmost extent of the 1887 surface rupture on the Otates fault is located within scree and is near the northern end of an outcrop of Permian carbonates (Fig. 4; (E)
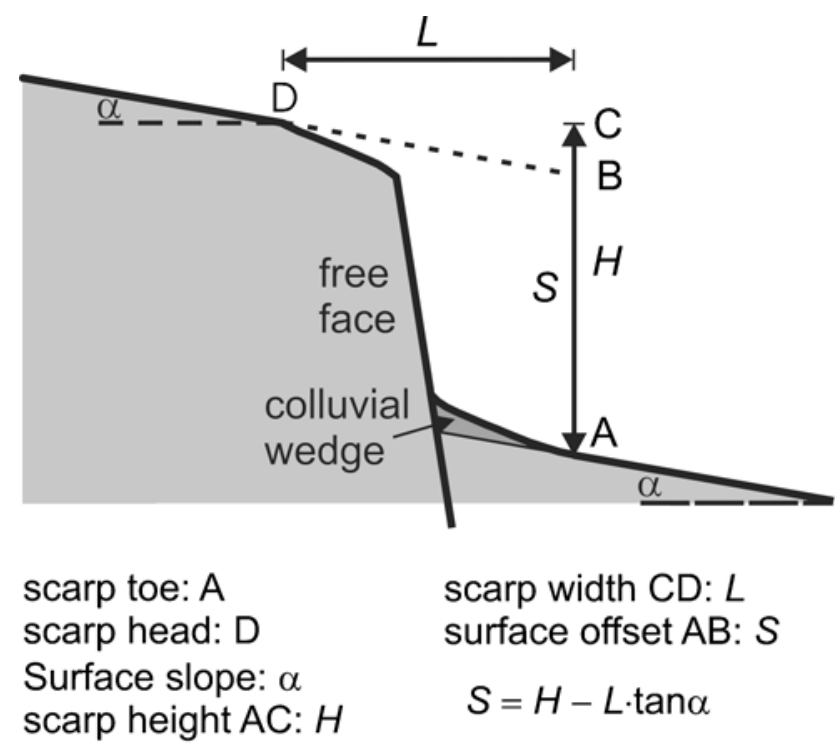

\section{scarp width CD: $L$ surface offset $A B: S$}

$$
S=H-L \cdot \tan \alpha
$$

Figure 7. Parameters used to characterize the 1887 surfacerupture scarp. The scarp width, the scarp height, and the height of the free face were determined with a level and tape measure at 23 sites along the Otates fault (Fig. 4; Table 1). Because of steep surface $(\alpha)$ adjacent to the scarp (as much as $31^{\circ}$ ), the surface offset $(S)$ is typically less than the scarp height $(H)$. 


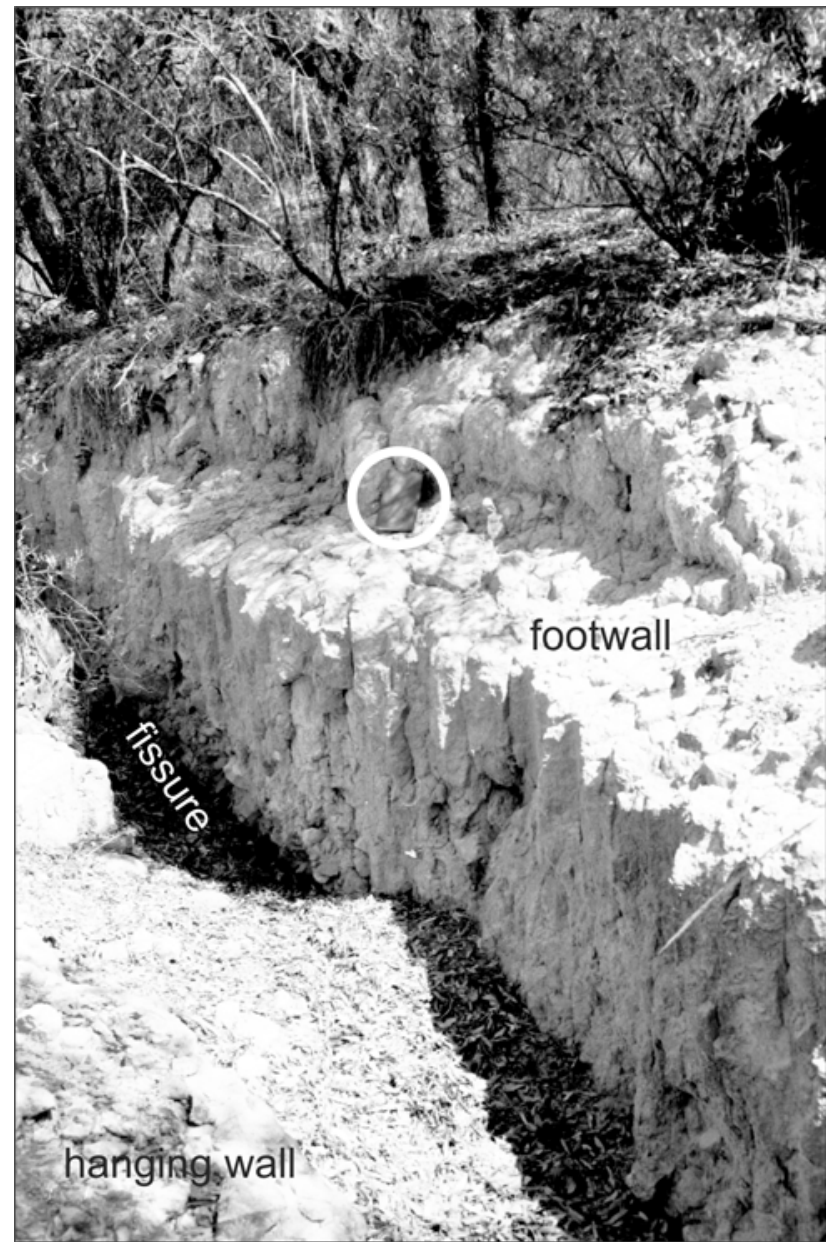

Figure 8. Photograph looking north along the 1887 earthquake rupture scarp at site 211 , near the southern end of the rupture (Fig. 4). The fault free face exposes scree composed of wellcemented rhyolite-derived material of $0.2-20 \mathrm{~cm}$ fragment size. An open fissure remains visible at the base of the scarp. A system of subparallel secondary shear fractures (synthetic Riedel shears) within the footwall suggests earlier right-lateral strike-slip motion along the Otates fault at this site. Notebook (white circle) for scale (21 cm long).

Fig. S10 in the electronic edition of BSSA). The northern surface-rupture termination may coincide with the junction of the Otates fault and the major northwest-southeast normal fault in its footwall (Fig. 3; (E) Fig. S2 in the electronic edition of BSSA). Apparently, the 1887 rupture did not extend up to the surface along the northernmost third of the Otates fault. The trace of the Otates fault, as well as the fill (Báucarit Formation) of the Higueras basin extend farther north than the surface rupture (Fig. 4). Therefore, the rupture is likely to be longer in the subsurface, especially if its displacement envelope is elliptical.

The 1887 surface rupture along the Otates is structurally simple; it is not internally segmented along strike and, unlike the Pitáycachi segment, it has no branches or subsidiary faults. It generally coincides with the mapped trace of the Otates fault (Fig. 4). Two exceptions are a rupture scarp observed at site 77 (Table 1) along a secondary normal fault
(Fig. 4) and a minor right stepover of the surface rupture near the Otates ranch (Figs. 3-5), which coincides with a stepover of the Otates fault ( $(E)$ Fig. S2 in the electronic edition of BSSA).

\section{Slip Vector}

Slickensides were observed on the surface-rupture fault plane in bedrock at four locations (from north to south, sites 27, 25, 23, and 79; Fig. 4; Table 2). In general, the striations indicate extensional dip slip without major lateral displacement; the minor right-lateral displacement with a rake of $105^{\circ}$ observed at site 23 is an exception. The dip-slip striations are in agreement with outcrop- to map-scale patterns of the rupture, which do not suggest any appreciable lateral motion along the Otates fault during the 1887 rupture. Contrary to these observations, a system of subparallel secondary shear fractures (synthetic Riedel shears) within the footwall at site 211 (Fig. 8) suggests earlier right-lateral strike-slip motion along the Otates fault on an outcrop scale. There is no evidence that these fractures were activated during the 1887 rupture. The average fault dip $(\bar{\beta})$ is $68^{\circ} \mathrm{W}$. This dip angle and existence of striations indicate that the near-surface part of the fault did not fail under tension as implied by the Mohr-Coulomb theory.

A kinematic analysis of the 1887 fault slip data using the program FaultKinWin (Marrett and Allmendinger, 1990; Allmendinger, 2001) is shown in Figure 10. This equalarea lower-hemisphere stereoplot contains the four measured fault planes and striations (Table 2) and their corresponding shortening $(P)$ and extension $(T)$ kinematic axes. Also shown are the average $P$ and $T$ kinematic axes (square symbols) and corresponding great circles representing the nodal planes of an earthquake focal mechanism for compressional waves ( $T$ quadrants shaded in gray). The average shortening axis $(P)$ trends $71^{\circ}$ and plunges $67^{\circ}$; the average extension axis (T) trends $264^{\circ}$ and plunges $23^{\circ}$. The fault plane of the focal mechanism strikes $170^{\circ}$ and dips $68^{\circ} \mathrm{W}$, whereas the auxiliary plane strikes $4^{\circ}$ and dips $23^{\circ} \mathrm{E}$. The result is similar to the composite focal mechanisms obtained by Natali and Sbar (1982) for microearthquakes in the region of the Pitáycachi segment of the 1887 rupture.

\section{Surface Offset and Coseismic Slip}

A distribution of the surface offsets measured at 22 sites (Table 1) along the rupture trace is shown in Figure 9. I have assumed the vertical separation of the ground surface to equal the measured free face value for those sites where the calculation of the ground surface separation resulted to be smaller than the free face. This assumption provides a minimum value for the ground surface offset. Furthermore, I have excluded the measurement from site 77, which is from a secondary rupture (Fig. 4). The maximum surface offset along the rupture trace is $250 \mathrm{~cm}$ at site 25 , the minimum surface offset is $70 \mathrm{~cm}$ at site 213 (Table 1), and the mean surface offset is $159 \mathrm{~cm}$. 


\section{OTATES SEGMENT}

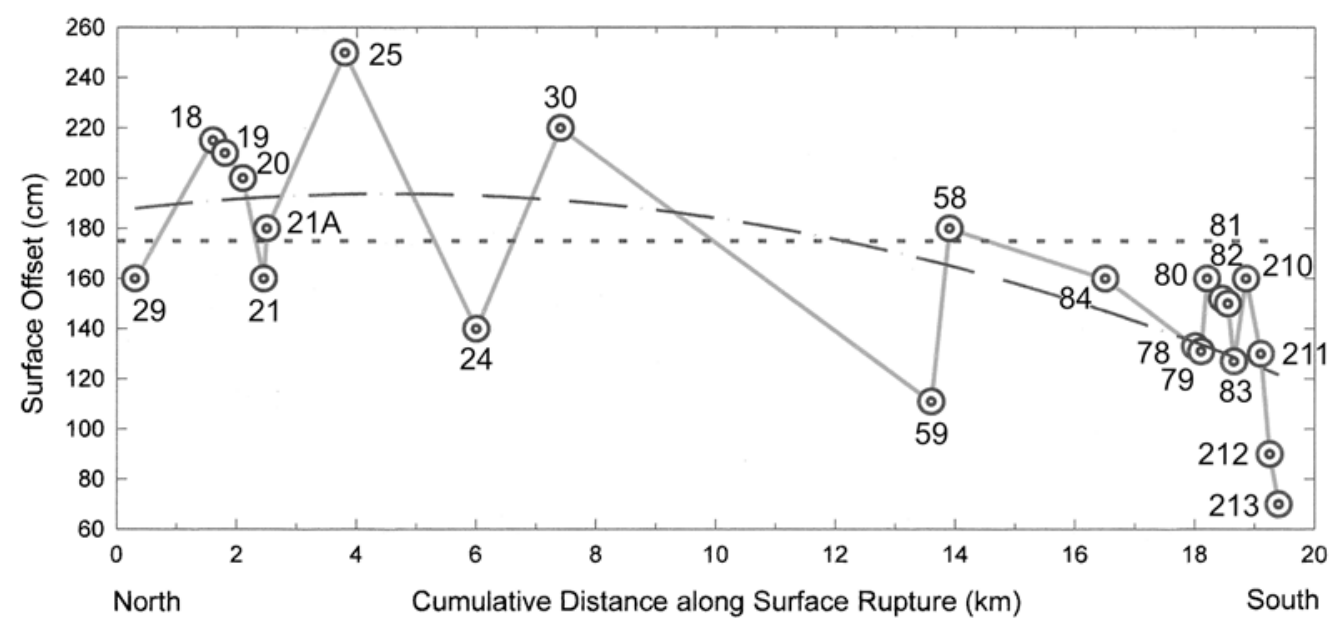

Figure 9. Surface offsets measured at 23 locations along the Otates segment of the 1887 earthquake rupture. The dashed line is a quadratic best fit. The dotted line indicates the average value $(175 \mathrm{~cm})$ of the regression. The distribution is asymmetric; the maximum surface offset $(250 \mathrm{~cm})$ is near the northern end of the segment.

The dashed line in Figure 9 is a quadratic best fit to the surface offset $y$-values. The distribution is asymmetric, with the maximum offset near the northern end of the segment. The regression curve corresponds to the function

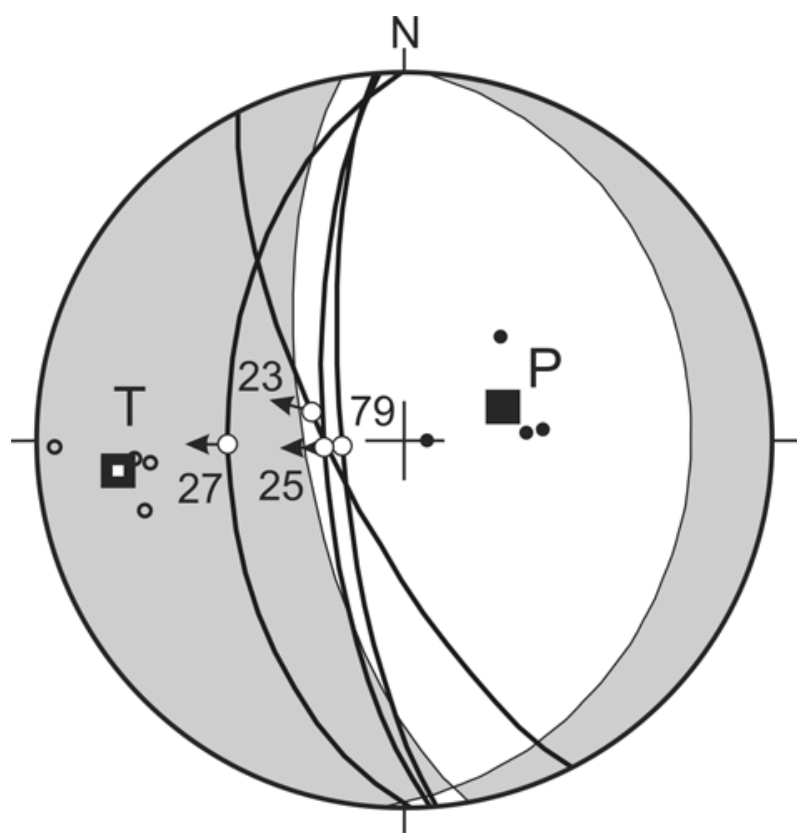

Figure 10. Lower-hemisphere equal-area stereoplot showing the four fault planes and striations measured along the 1887 surface rupture (Table 2). $P$ (shortening) and $T$ (extension) kinematic axes are represented by black and open circles, respectively. Average $P$ and $T$ kinematic axes (heavy black squares) and corresponding great circles representing potential earthquake focal mechanism nodal planes ( $T$ quadrant shaded in gray) are also shown. The striations indicate extensional dip-slip motion without major lateral displacement. The focal mechanism fault plane strikes $170^{\circ}$ and dips $68^{\circ} \mathrm{W}$, whereas the auxiliary plane strikes $4^{\circ}$ and dips $23^{\circ} \mathrm{E}$.

$$
y=a x^{2}+b x+c,
$$

where $a=-0.33, b=2.96$, and $c=187$. The correlation coefficient is 0.7019 . The asymmetrical profile of the surface offsets can be explained by the mechanical interaction of the Teras and Otates surface-rupture segments through their stress fields (Suter and Contreras, 2002) because in a system of en echelon normal faults, the point of maximum displacement is shifted toward the interacting tip (Willemse, 1997; Gupta and Scholz, 2000).

The average value $(\bar{y})$ of the regression function is $175 \mathrm{~cm}$ (dotted horizontal line on Fig. 9). This value corresponds to the area below the regression curve divided by the difference between the limits of integration, which are the cumulative distances of the northernmost and southernmost measurement sites along the surface rupture (Table 1; Fig. 9).

$$
\begin{aligned}
\bar{y} & =\frac{1}{x_{213}-x_{29}} \int_{x_{29}}^{x_{213}}\left(a x^{2}+b x+c\right) d x \\
& =\frac{1}{x_{213}-x_{29}}\left[a \frac{x^{3}}{3}+b \frac{x^{2}}{2}+c x\right]_{x_{29}}^{x_{213}} .
\end{aligned}
$$

The average value of the regression function $(175 \mathrm{~cm})$ is greater than the mean of the individual surface offsets $(159 \mathrm{~cm})$ because most measurements were taken at either end of the surface rupture (Fig. 9) where the surface offsets taper off. The average value of the regression is therefore likely to be more representative of average offset than the mean of the individual surface offsets.

The ground surface offset distribution can be used to estimate the coseismic slip distribution at depth. The transform from surface offset $y$ to slip $s$ is 


$$
s=y / \sin \bar{\beta} .
$$

As indicated previously, the average $\operatorname{dip} \bar{\beta}$ is $68^{\circ} \mathrm{W}$. Based on equation (3), the maximum slip at depth along the Otates fault in the 1887 earthquake was $270 \mathrm{~cm}$, the slip resulting from the arithmetic average of the vertical separation measurements is $171 \mathrm{~cm}$, and the slip resulting from the average value of the regression function is $189 \mathrm{~cm}$.

\section{Slip Rate and Recurrence Interval}

To date, no Quaternary slip rate has been calculated for the Otates fault. Basin and Range Province faults that separate bedrock from internally unfaulted basin fill, such as the Otates fault, typically have vertical slip rates $>0.1 \mathrm{~mm} / \mathrm{yr}$ (dePolo and Anderson, 2000). As mentioned previously, the estimated geologic slip rate of the Otates fault is $0.06 \mathrm{~mm} / \mathrm{yr}$ based on an estimated throw of $1360 \mathrm{~m}$ along a $68^{\circ}$ dipping fault over a period of $23 \mathrm{Myr}$. A rough estimate of the average recurrence interval of 1887-sized earthquakes on the Otates fault can be obtained from this slip rate and the amount of slip on this segment during the 1887 earthquake; the resulting values are $42 \mathrm{kyr}$ based on the maximum slip, $27 \mathrm{kyr}$ based on the slip resulting from the arithmetic average of the vertical separation measurements, and $30 \mathrm{kyr}$ based on the slip resulting from the average value of the regression function. These estimates are within the range of recurrence intervals documented for normal faults of the southern Basin and Range Province and the Río Grande rift (10-100 kyr; Menges and Pearthree, 1989; Machette, 1998).

The change in Coulomb failure stress caused by the rupture of individual segments of a fault zone may advance or delay the rupture of adjacent segments (King et al., 1994; Stein, 1999). This suggests that the various segments of the fault zone on the western edge of the Sierra Madre Occidental Plateau may have failed in the past in segment combinations that are different from the one that ruptured in 1887 (Pitáycachi-Teras-Otates). This might result in major fluctuations of the recurrence intervals for the individual fault segments.

\section{Rupture Kinematics}

The structural configuration of the 1887 rupture along the Otates fault does not indicate where the rupture originated and how it propagated. Conversely, the surface rupture along the Pitáycachi segment has a well-developed branching pattern (five north-facing bifurcations in the northern part of the segment and two south-facing bifurcations in its southern part). This suggests that the rupture of the Pitáycachi segment initiated in its central part where the polarity of the rupture bifurcations changes (Suter and Contreras, 2002). I consider it likely that the rupture first propagated bilaterally along the Pitáycachi fault, from where the southern rupture front jumped across the stepover to the Teras fault () Fig. S2 in the electronic edition of BSSA) and from there to the Otates fault (Fig. 2). This hypothesis is supported by the macroseismic observations made by Aguilera (1888), which indicate that this event was a composite earthquake with subevents separated by several seconds. Geological observations elsewhere indicate that historical Basin and Range Province earthquakes with large magnitudes involved sequential rupture of two or more discrete segments (dePolo et al., 1991; Zhang et al., 1999). Furthermore, in a study of the source parameters of Basin and Range Province earthquakes, Doser and Smith (1989) conclude that earthquakes of magnitude $\geq 7.0$ have complex ruptures best modeled by multiple subevents. Finally, the directivity effect of a northto-south propagating rupture along the southern part of the Pitáycachi fault and the Teras and Otates faults also explains why the isoseismals of this earthquake (Aguilera, 1888; Suter, 2006) are so much elongated in a southsoutheast direction.

Structural Interaction between the Teras and Otates Rupture Segments

A $15 \mathrm{~km}$ long gap separates the northern end of the Otates segment from the southern end of the Teras segment (Figs. 2 and 3). Assuming the rupture propagated from north to south, the 1887 rupture was arrested along the southern Teras fault where the fault trace has a $60^{\circ}$ bend and jogs to the west (Suter, 2008; (E) Fig. S2 in the electronic edition of BSSA). A model of changes in Coulomb failure stress resulting from the rupture indicates lobes of increased stress at the tips of the 1887 rupture segments, especially in the stepover between the Teras and Otates faults (Suter and Contreras, 2002). The northern part of the Otates fault and the northern parts of the normal faults bounding the Iglesitas horst (Fig. 3; (E) Fig. S2 in the electronic edition of BSSA) are located in this zone of stress concentration. Therefore, the 1887 rupture could have either jumped from the Teras to the Otates fault or triggered slip along the faults bounding the Iglesitas horst. However, field-checking the fault traces along the Iglesitas horst did not reveal any obvious morphological or stratigraphic evidence of Quaternary fault activity.

The Otates surface-rupture segment has greater surface offset (vertical separation) values than the Teras segment to the north, even though the Teras segment is slightly longer (Suter and Contreras, 2002; Suter, 2008). This suggests that the Otates rupture segment may be longer than mapped. This hypothesis is also supported by the high surface offset values at the northern end of the mapped surface rupture of the Otates segment (Fig. 9). Furthermore, the high surface offset values at the southern end of the mapped surface rupture of the Teras segment and at the northern end of the mapped surface rupture of the Otates segment suggest that the two segments could be part of a single continuous rupture that stepped across the structurally complex basement ridge between them. However, our mapping has provided no evidence of young surface rupture on this basement ridge. 


\section{Historical Evidence for the Otates Fault Rupture during the 3 May 1887 Earthquake}

The Pitáycachi rupture segment was mapped shortly after the 3 May 1887 earthquake (Goodfellow 1887, 1888; Aguilera, 1888; Suter, 2006). Goodfellow (1888) describes a possible $24 \mathrm{~km}$ long southern continuation of the surface rupture, beyond the mapped segment, into the Teras mountain range based on observations made by prospectors (Teras segment on Fig. 2). The existence of the surface rupture along the Otates fault, on the other hand, was unknown to Aguilera and Goodfellow and was reported only recently (Suter and Contreras, 2002). Here, I provide historical evidence that the surface rupture along the Otates fault formed during the 3 May 1887 earthquake.

Aftershocks were reported from the Otates fault region by Vázquez (1887) in a letter from Bavispe, dated 29 May 1887. According to Vázquez, the aftershocks were frequent, lasted 9-12 sec, and were accompanied by subterranean rumblings and detonation sounds coming from Sierra de la Madera, located $17 \mathrm{~km}$ west of Bavispe (Fig. 2). Vázquez reported similar observations from the communities of Bacerac, Huachineras, Estancia, Galera, and San Miguelito, which are also located in the Bavispe River valley, east of the Sierra de la Madera mountain range (E) Fig. S2 in the electronic edition of BSSA).

Rupture along the Otates fault may explain why the most severe damage caused by the 1887 earthquake was in Bavispe and Óputo (now Villa Hidalgo) (Aguilera, 1888; Goodfellow, 1888). Both towns are located closer to the Otates segment than to the previously known Teras and Pitáycachi rupture segments (Fig. 2). However, severe ground shaking may also be due to local site conditions, because these two towns are built on alluvium of the Bavispe River (Fig. 2). Furthermore, the duration and amplitude of ground motion at Bavispe and Óputo may have been additionally enhanced by a directivity effect (Somerville et al., 1997; Rowshandel, 2006) if the 1887 rupture along the Teras and Otates segments propagated from north to south as previously postulated.

Mallet (1862) interpreted detached masses of masonry to be overthrown in the propagation direction of the earthquake waves. He located the epicenter of the 1857 Neapolitan earthquake from the intersection of the backprojection of such directions (Davison, 1927; Oeser, 2003). Mallet's hypothesis was supported by Sekiya and Omori (1895). They found the mean fall direction of 245 stone lanterns to be identical with that of the maximum horizontal ground motion recorded instrumentally during the Tokyo earthquake of 20 June 1894.

The prevalent falling direction of toppled walls at Bavispe and Óputo was reported by Aguilera (1888) and Goodfellow (1888). At Bavispe, walls facing the west side of the plaza and oriented north-south fell toward the east. Conversely, houses on the south side of the plaza, oriented east-west, were not seriously damaged (Goodfellow, 1888).
At Óputo, on the other hand, "of the walls thrown down, with two or three exceptions, all fell to the westward, though the upper portion of a few of the east-and-west walls had toppled over to the south" (Goodfellow, 1888). Lines drawn in these preferential toppling directions intersect in the general area of the Otates rupture segment (Fig. 2) and not in the regions of the Teras or Pitáycachi segments. This supports the hypothesis that the rupture scarp along the Otates fault developed during the 1887 earthquake rather than during an earlier or later earthquake.

The region of the Otates fault was not visited by either the Goodfellow (1888) or Aguilera (1888) field parties. Their studies do not preclude that the surface rupture along the Otates fault formed in the 1887 earthquake. The 1887 expedition of the Comisión Científica de Sonora into the epicentral region crossed Sierra El Tigre on the trail that leads from Villa Hidalgo (formerly Óputo) to Huachineras (Aguilera, 1888; Suter, 2007). This route brought them approximately $15 \mathrm{~km}$ south of the documented southern end of the Otates fault surface rupture (Fig. 2).

Finally, oral history supports that the Otates fault ruptured during the 3 May 1887 earthquake. According to the Medina brothers, owners of Los Otates ranch, the prominent surface rupture on their property (Fig. 4; (E) Fig. S8 in the electronic edition of BSSA) formed before their father's birth in 1910. Therefore, the rupture cannot be the result of the 17 May 1913 Huásabas, Sonora $\left(I_{\max }=\right.$ VIII, $\left.M_{I} 5.0 \pm 0.4\right)$ or the 18 December 1923 Granados-Huásabas, Sonora $\left(I_{\max }=\mathrm{IX}, M_{I} 5.7 \pm 0.4\right)$ earthquakes (Suter, 2001). Both events caused severe damage $40-50 \mathrm{~km}$ south of the documented southern tip of the 1887 rupture, along the same fault zone, in the Granados-Huásabas region (Fig. 1).

\section{Conclusions}

The seismogenic Otates fault (southern Basin and Range Province) forms part of a major fault zone that defines the western margin of the Sierra Madre Occidental Plateau in northeastern Sonora. Basin and Range Province faulting began here about $23 \mathrm{Myr}$ ago. The fault is characterized by extensional dip-slip motion. It is approximately $30 \mathrm{~km}$ long with an average dip of $68^{\circ}$. We estimate the fault has experienced more than $1360 \mathrm{~m}$ of throw in its central part over the last $23 \mathrm{Ma}$, resulting in a long-term slip rate of $0.06 \mathrm{~mm} / \mathrm{yr}$. The associated fault-bounded Higueras basin is filled with as much as $250 \mathrm{~m}$ of well-indurated, poorly stratified conglomerate and sandstone of the syntectonic Báucarit Formation. A transverse reconnaissance of the adjacent regional-scale structures of the Sonoran Basin and Range Province indicates about $10 \%$ east-west extension caused by subvertical normal faults, each with 1-2 km of throw, and a distance of $10-15 \mathrm{~km}$ between adjacent horsts or basins.

During the great 3 May 1887 Sonoran earthquake (surface-rupture end-to-end length: $101.8 \mathrm{~km} ; M_{\mathrm{W}} 7.5 \pm$ 0.3 ), three neighboring fault segments (Otates, Teras, and Pitáycachi, from south to north) slipped along the western 
margin of the Sierra Madre Occidental Plateau. This study shows that the previously unmapped surface rupture along the Otates fault dips $68^{\circ} \mathrm{W}$ and is $18.2 \mathrm{~km}$ long. The lateral rupture terminations are controlled by cross faults. Slickensides indicate extensional dip-slip motion without major lateral displacement. The morphology of the 120-year-old scarp was studied at 23 sites. The free face still exists at all of these sites. The surface offset has a maximum of $250 \mathrm{~cm}$ and an arithmetic mean of $159 \mathrm{~cm}$, whereas a quadratic best fit to the surface offset distribution indicates a more representative average of $175 \mathrm{~cm}$. The along-rupture surface offsets are asymmetrically distributed, with the maximum offset located near the northern tip of the segment, which can be explained by the mechanical interaction of the Otates and the adjacent Teras surface-rupture segments through their stress fields. The average recurrence interval of 1887-sized earthquakes on the Otates fault is $30-42 \mathrm{kyr}$ based on the estimated long-term geologic slip rate of the fault and its magnitude of slip in the 1887 earthquake. The surface rupture along the Pitáycachi segment has a well-developed branching pattern (five north-facing bifurcations in the northern part of the segment and two south-facing bifurcations in its southern part). This suggests that the rupture of the Pitáycachi segment initiated in its central part where the polarity of the rupture bifurcations changes. It is therefore likely that the rupture first propagated bilaterally along the Pitáycachi fault, from where the southern rupture front jumped across a stepover to the Teras fault and another one to the Otates fault.

Rupture along the Otates fault explains why the damage caused by the 1887 earthquake was the most severe in Bavispe and Óputo (now Villa Hidalgo); both towns are located closer to the Otates segment than to the previously known Teras and Pitáycachi rupture segments. However, severe ground shaking may also be due to the local site conditions, because these two towns are built on alluvium of the Bavispe River. The duration and amplitude of ground motion at Bavispe and Óputo may have been additionally enhanced by a directivity effect if the 1887 rupture along the Teras and Otates segments propagated from north to south.

\section{Data and Resources}

The digital elevation model (DEM) of northeastern Sonora (Fig. 2) was created from Shuttle Radar Topography Mission data; the DEM of the Otates fault region (Fig. 3) was created from data supplied by the Instituto Nacional de Estadística, Geografía e Informática (INEGI). The colorcoded DEM in the electronic supplement was concatenated from U.S. Geological Survey and INEGI data. All DEMs were processed with Surfer®8 (www.goldensoftware.com). The regression analysis and plotting of the surface offset data (Fig. 9) was done with SigmaPlot ${ }^{\circledR}$. For the kinematic analysis and plotting of the 1887 fault slip data (Fig. 10), I used the program FaultKinWin, developed by R. W. Allmendinger (version 1.2, 2001), courtesy of ftp://www.geo.cornell.edu/
pub/rwa/Windows. The ortho-rectified Landsat-7 ETM+ false-color image data in the electronic supplement were supplied by the U.S. Geological Survey and processed with MultiSpec 2.7 (Biehl and Landgrebe, 2002), an image data analysis program developed at the School of Electronic and Computer Engineering of Purdue University.

\section{Acknowledgments}

I thank BSSA Associate Editor Mark Hemphill-Haley, Mike Machette, Judith Zachariasen, and an anonymous referee for their careful and thoughtful reviews of the manuscript. This project was made possible in part by financial and logistic support from Universidad Nacional Autónoma de México (UNAM) and Consejo Nacional de Ciencia y Tecnología (CONACYT, Grant Number G33102-T).

\section{References}

Aguilera, J. G. (1888). Estudio de los fenómenos séismicos del 3 de mayo de 1887, An. Minist. Fomento Repúb. Mex. 10, 5-56.

Aguirre-Díaz, G. J., J. Nieto-Obregón, and F. R. Zúñiga (2005). Seismogenic Basin and Range and intra-arc normal faulting in the central Mexican volcanic belt, Querétaro, México, Geol. J. 40, 215-243.

Allmendinger, R. W. (2001). FaultKinWin program, version 1.2, available at ftp://www.geo.cornell.edu/pub/rwa/Windows (last accessed October 2008).

Anderson, T. H., and L. T. Silver (1977). U-Pb isotope ages of granitic plutons near Cananea, Sonora, Econ. Geol. 72, 827-836.

Aranda-Gómez, J. J., and C. D. Henry (1992). Fallamiento cuaternario cerca de la ciudad de Durango-naturaleza del período de deformación mas joven relacionado a extensión multiepisódica en el noroeste de México, GEOS, Unión Geofís. Mex. Bol. Inform. 12, no. 5, 53-54.

Aranda-Gómez, J. J., C. D. Henry, J. F. Luhr, and F. W. McDowell (1997). Cenozoic volcanism and tectonics in NW Mexico: a transect across the Sierra Madre Occidental volcanic field and observations on extension related magmatism in the southern Basin and Range and Gulf of California tectonic provinces, in Magmatism and Tectonics in the Central and Northwestern Mexico-A Selection of the 1997 IAVCEI General Assembly Excursions, G. J. Aguirre-Díaz, J. J. Aranda-Gómez, G. Carrasco-Nuñez and L. Ferrari (Editors), Universidad Nacional Autónoma de México, Instituto de Geología, México, D.F. 41-84.

Aranda-Gómez, J. J., J. F. Luhr, T. B. Housh, C. B. Connor, T. Becker, and C. D. Henry (2003). Synextensional Pliocene-Pleistocene eruptive activity in the Camargo volcanic field, Chihuahua, México, Geol. Soc. Am. Bull. 115, 298-313.

Bakun, W. H. (2006). MMI attenuation and historical earthquakes in the Basin and Range Province of western North America, Bull. Seismol. Soc. Am 96, 2206-2220.

Biehl, L., and D. Landgrebe (2002). MultiSpec-a tool for multispectralhyperspectral image data analysis, Comput. Geosci. 28, 1153-1159.

Bucknam, R. C., and R. E. Anderson (1979). Estimation of fault-scarp ages from a scarp-height slope-angle relationship, Geology 7, 11-14.

Bull, W. B., and P. A. Pearthree (1988). Frequency and size of Quaternary surface rupture of the Pitaycachi fault, northeastern Sonora, Mexico, Bull. Seismol. Soc. Am. 78, 956-978.

Castro, R., C. Condori, O. Romero, C. Jacques, and M. Suter (2008). Seismic attenuation in northeastern Sonora, Mexico, Bull. Seismol. Soc. Am. 98, 722-732.

Contreras, J., and C. H. Scholz (2001). Evolution of stratigraphic sequences in multisegmented continental rift basins-comparison of computer models with the basins of the East African rift system, Am. Assoc. Pet. Geol. Bull. 85, 1565-1581.

Davison, C. (1927). The Founders of Seismology, Cambridge University Press, Cambridge, 240 pp. 
Demant, A., J. J. Cochemé, P. Delpretti, and P. Piguet (1989). Geology and petrology of the Tertiary volcanics of the northwestern Sierra Madre Occidental, Mexico, Bull. Soc. Géol. France, série 8, 5, 737-748.

dePolo, C. M., and J. G. Anderson (2000). Estimating the slip rates of normal faults in the Great Basin, USA, Basin Res. 12, 227-240.

dePolo, C. M., D. G. Clark, D. B. Slemmons, and A. R. Ramelli (1991). Historical surface faulting in the Basin-and-Range Province, western North America-implications for fault segmentation, J. Struct. Geol. 13, 123-136.

Doser, D. I., and J. Rodríguez (1993). The seismicity of Chihuahua, Mexico, and the 1928 Parral earthquake, Phys. Earth Planet. Interiors 78, $97-104$.

Doser, D. I., and R. B. Smith (1989). An assessment of source parameters of earthquakes in the Cordillera of the western United States, Bull. Seismol. Soc. Am. 79, 1383-1409.

DuBois, S. M., and A. W. Smith (1980). The 1887 earthquake in San Bernardino Valley, Sonora, State of Arizona, Bureau of Geology and Mineral Technology Special Paper 3, 112 pp.

García, Acosta V., and G. Suárez Reynoso (1996). Los Sismos en la Historia de México, Universidad Nacional Autónoma de México and Fondo de la Cultura Económica, Mexico City, 718 pp.

Gawthorpe, R. L., and M. R. Leeder (2000). Tectono-sedimentary evolution of active extensional basins, Basin Res. 12, 195-218.

González-León, C. M., W. C. McIntosh, R. Lozano-Santacruz, M. ValenciaMoreno, R. Amaya-Martínez, and J. L. Rodríguez-Castañeda (2000). Cretaceous and Tertiary sedimentary, magmatic, and tectonic evolution of north-central Sonora (Arizpe and Bacanuchi Quadrangles), northwest Mexico, Geol. Soc. Am. Bull. 112, 600-610.

Goodfellow, G. E. (1887). The Sonora earthquake, Science 10, no. 236, 81-82.

Goodfellow, G. E. (1888). The Sonora earthquake, Science 11, no. 270, $162-166$.

Gupta, A., and C. H. Scholz (2000). A model of normal fault interaction based on observations and theory, J. Struct. Geol. 22, 865-879.

Henry, C. D., and J. J. Aranda-Gómez (2000). Plate interactions control middle-late Miocene, proto-Gulf and Basin and Range extension in the southern Basin and Range, Tectonophysics 318, 1-26.

Jackson, J., and M. Leeder (1994). Drainage systems and the development of normal faults-an example from Pleasant Valley, Nevada, J. Struct. Geol. 16, 1041-1059.

Kanamori, H., and L. Rivera (2006). Energy partitioning during an earthquake, in Earthquakes: Radiated Energy and the Physics of Faulting, R. Abercrombie, A. McGarr, G. DiToro and H. Kanamori (Editors), American Geophysical Monograph 170, 3-13.

King, G. C. P., R. S. Stein, and J. Lin (1994). Static stress changes and the triggering of earthquakes, Bull. Seismol. Soc. Am. 84, 935-953.

Machette, M. N. (1998). Contrasts between short-term and long-term records of seismicity, in The Río Grande Rift-Important Implications for Seismic-Hazard Assessments in Areas of Slow Extension, Basin and Range Province Seismic-Hazards Summit, W. R. Lund (Editor), Utah Geol. Surv. Misc. Publ. 98, no. 2, 84-95.

Machette, M. N., S. F. Personius, A. R. Nelson, D. P. Schwartz, and W. R. Lund (1991). The Wasatch fault zone, Utah-segmentation and history of Holocene earthquakes, J. Struct. Geol 13, 137-149.

Mallet, R. (1862). Great Neapolitan Earthquake of 1857: The First Principles of Observational Seismology, Vol. 2, Chapman \& Hall, London, $854 \mathrm{pp}$.

Márquez-Azúa, B., and C. DeMets (2003). Crustal velocity field of Mexico from continuous GPS measurements, 1993 to June 2001implications for the neotectonics of Mexico, J. Geophys. Res. 108, no. B9, 2450, doi 10.1029/2002JB002241.

Marrett, R., and R. W. Allmendinger (1990). Kinematic analysis of fault-slip data, J. Struct. Geol. 12, 973-986.

McCalpin, J. P. (1996). Paleoseismology, Academic, New York, 588 pp.

McDowell, F. W., J. Roldán-Quintana, and R. Amaya-Martínez (1997). Interrelationship of sedimentary and volcanic deposits associated with
Tertiary extension in Sonora, Mexico, Geol. Soc. Am. Bull. 109, 1349-1360.

McIntosh, W. C., and C. Bryan (2000). Chronology and geochemistry of the Boot Heel volcanic field, New Mexico, in Southwest Passage: A Trip through the Phanerozoic, New Mexico Geological Society Guidebook, Fifty-First Annual Field Conference, T. F. Lawton, N. J. McMillan and V. T. McLemore (Editors), New Mexico Geological Society, Socorro, 157-174.

Menges, C. M., and P. A. Pearthree (1989). Late Cenozoic tectonism in Arizona and its impact on regional landscape evolution, Ariz. Geol. Soc. Dig. 17, 649-680.

Mishler, R. T. (1920). Geology of the El Tigre District, Min. Sci. Press 121, 583-591.

Montaño-Jiménez, T. R. (1988). Geología del área de El Tigre, noreste de Sonora, B. Sc. Thesis, Universidad de Sonora, Hermosillo, Sonora, $135 \mathrm{pp}$.

Montigny, R., A. Demant, P. Delpretti, P. Piguet, and J. J. Cochemé (1987). Chronologie K/Ar des séquences volcaniques tertiaires du nord de la Sierra Madre Occidental (Mexique), C. R. Acad. Sci., série II, 304, no. $16,987-992$.

Nakata, J. K., C. M. Wentworth, and M. N. Machette (1982). Quaternary fault map of the Basin and Range and Rio Grande rift provinces, western United States, U.S. Geol. Surv. Open-File Rept. 82-579, 1:2,500,000 scale.

Natali, S. G., and M. L. Sbar (1982). Seismicity in the epicentral region of the 1887 northeastern Sonora earthquake, Mexico, Bull. Seismol. Soc. Am. 72, 181-196.

Oeser, E. (2003). Historische Erdbebentheorien von der Antike bis zum Ende des 19. Jahrhunderts, Abh. Geol. Bundesanst. (Austria) 58, $204 \mathrm{pp}$.

Orozco y Berra, J. (1887). Efemérides séismicas Mexicanas, Mem. Soc. Cient. Antonio Alzate 1, 303-541 (Mexico).

Paz Moreno, F. A., A. Demant, J. J. Cochemé, J. Dostal, and R. Montigny (2003). The Quaternary Moctezuma volcanic field-a tholeiitic to alkali basaltic episode in the central Sonoran Basin and Range Province, México, in Tectonic Evolution of Northwestern México and the Southwestern USA, S. E. Johnson, S. R. Paterson, J. M. Fletcher, G. H. Girty, D. L. Kimbrough and A. Martín-Barajas (Editors), Geological Society of America Special Paper 374, 439-455.

Rowshandel, B. (2006). Incorporating source rupture characteristics into ground-motion hazard analysis models, Seism. Res. Lett. 77, no. 6, 708-722.

Sbar, M. L., and S. M. DuBois (1984). Attenuation of intensity for the 1887 northern Sonora, Mexico earthquake, Bull. Seismol. Soc. Am. 74, 2613-2628.

Scholz, C. H. (2002). The Mechanics of Earthquakes and Faulting, Second Ed., Cambridge University Press, Cambridge, 471 pp.

Sekiya, S., and F. Omori (1895). The diagram of the semi-destructive earthquake of June 20th, 1894, Imperial University, Japan, J. Coll. Sci. 7, part 4, 289-292.

Shipton, Z. K., J. P. Evans, R. E. Abercrombie, and E. E. Brodsky (2006). The missing sinks: slip localization in faults, damage zones, and the seismic energy budget, in Earthquakes: Radiated Energy and the Physics of Faulting, R. Abercrombie, A. McGarr, G. DiToro and H. Kanamori (Editors), American Geophysical Monograph 170, 217-222.

Sibson, R. H. (2003). Thickness of the seismic slip zone, Bull. Seismol. Soc. Am. 93, 1169-1178.

Somerville, P. G., N. F. Smith, R. W. Graves, and N. A. Abrahamson (1997). Modification of empirical strong ground motion attenuation relations to include the amplitude and duration effects of rupture directivity, Seism. Res. Lett. 68, 199-222.

Stein, R. S. (1999). The role of stress transfer in earthquake occurrence, Nature 402, 605-609.

Stewart, J. H. (1998). Regional characteristics, tilt domains, and extensional history of the late Cenozoic Basin and Range Province, western North 
America, in Accommodation Zones and Transfer Zones: The Regional Segmentation of the Basin and Range Province, J. E. Faulds and J. H. Stewart (Editors), Geological Society of America Special Paper 323, $47-74$.

Suter, M. (1991). State of stress and active deformation in Mexico and western Central America, in Neotectonics of North America, D. B. Slemmons, E. R. Engdahl, M. D. Zoback and D. D. Blackwell (Editors), Decade of North American Geology, Decade Map Vol. 1, Geological Society of America, Boulder, Colorado, 401-421.

Suter, M. (2001). The historical seismicity of northeastern Sonora and northwestern Chihuahua, Mexico $\left(28-32^{\circ} \mathrm{N}, 106-111^{\circ} \mathrm{W}\right), \mathrm{J}$. South Am. Earth Sci. 14, 521-532.

Suter, M. (2004). A neotectonic-geomorphologic investigation of the prehistoric rock avalanche damming Laguna de Metztitlán (Hidalgo State, east-central Mexico), Rev. Mex. Cien. Geol. 21, 397-411.

Suter, M. (2006). Contemporary studies of the 3 May $1887 M_{\mathrm{w}} 7.5$ Sonora, Mexico (Basin and Range Province) earthquake, Seism. Res. Lett. 77, no. 2, 134-147.

Suter, M. (2007). The first geologic map of Sonora, Bol. Soc. Geol. Mex. 59, $1-7$.

Suter, M. (2008). Structural configuration of the Teras fault (southern Basin and Range Province) and its rupture in the 3 May $1887 M_{\mathrm{W}} 7.5$ Sonora, Mexico earthquake, Rev. Mex. Cien. Geol. 25, 179-195.

Suter, M., and J. Contreras (2002). Active tectonics of northeastern Sonora, Mexico (southern Basin and Range Province) and the 3 May 1887 $M_{\mathrm{w}} 7.4$ earthquake, Bull. Seismol. Soc. Am. 92, 581-589.

Suter, M., M. Carrillo, and O. Quintero (1996). Macroseismic study of shallow earthquakes in the central and eastern parts of the Trans-Mexican volcanic belt, Mexico, Bull. Seismol. Soc. Am. 86, 1952-1963.

Vázquez, L. (1887). El terremoto del 3 de Mayo, La Constitución, Periódico Oficial del Gobierno del Estado 9, no. 24, 1-2.
Vermilye, J. M., and C. H. Scholz (1998). The process zone-a microstructural view of fault growth, J. Geophys. Res. 103, 12,223-12,237.

Wells, D. L., and K. J. Coppersmith (1994). New empirical relationships among magnitude, rupture length, rupture width, rupture area, and surface displacement, Bull. Seismol. Soc. Am. 84, 974-1002.

Willemse, E. J. M. (1997). Segmented normal faults-correspondence between three-dimensional mechanical models and field data, $J$. Geophys. Res. 102, 675-692.

Yamamoto, J. (1993). Actividad microsísmica en el área de Canatlán, Durango, y su relación con la geología regional, Geofís. Int. 32, 501-510.

Yeats, R. S., K. Sieh, and C. R. Allen (1997). The Geology of Earthquakes, Oxford University Press, Oxford, 568 pp.

Zhang, P., F. Mao, and D. B. Slemmons (1999). Rupture terminations and size of segment boundaries from historical earthquake ruptures in the Basin and Range Province, Tectonophysics 308, 37-52.

Zúñiga, F. R., J. F. Pacheco, M. Guzmán-Speziale, G. J. Aguirre-Díaz, V. H. Espíndola, and E. Nava (2003). The Sanfandila earthquake sequence of 1998, Queretaro, Mexico-activation of an undocumented fault in the northern edge of central Trans-Mexican volcanic belt, Tectonophysics 361, 229-238.

Instituto de Geología

Universidad Nacional Autónoma de México

Estación Regional del Noroeste

Hermosillo, Sonora, Mexico

SuterMax@aol.com

Manuscript received 22 November 2006 